\title{
New Directions of Maternal Factors and Ultrasound Markers in the Prediction of Early and Late Pre-Eclampsia
}

Kashami Arian

PhD Candidate

Gliozheni Orion

Prof. Dr.

Troshani Amela

MA, MSc

University Hospital of Obstetrics and Gynecology

"Koço Gliozheni", Tirana, Albania

Shabani Zamira

Assoc. Prof. Dr. University of Shkodra "Luigj Gurakuqi"

Faculty of natural Sciences, Shkoder, Albania

\section{Abstract}

Pre-eclampsia (PE) is one of the hypertensive pregnancy disorders, de novo protein-uric hypertension that develops after 20 weeks of gestation and it is a systemic disorder associated with high maternal and neonatal morbidity and mortality. The aim of this study was to determine the usefulness as a screening method for early- and late-onset pre-eclampsia of a combination of a series of measurements, including maternal characteristics and UtA Doppler measured at $11+0$ to $13+6$ weeks of gestation and 22 to 24 weeks of gestation. This is a retrospective cohort study, during January - December 2017, of women who have had Pre-eclampsia at a tertiary referral University Hospital of Obstetrics and Gynecology "Koço Gliozheni" in Tirana, Albania. In total were 62 women with Pre-eclampsia during this period of time. Maternal and neonatal data were collected from the case notes and was done uterine artery color Doppler examination at 22-24 weeks of gestation. The ultrasound machine used was Aloka Echo Camera L. All data were calculated with SPSS 15.0. T-test, Chi-Square test, Fisher test and Correlation were used for statistical analysis. In total, 62 women with Pre-eclampsia were classified: $32 \%$ Early PE and 68\% Late PE. In Doppler examination $26 \%$ had bilateral notch at uterine artery, $12 \%$ notch at AU Dexter, $15 \%$ notch at AU Sinister and $47,1 \%$ without notch. $58.8 \%$ Apgar score in the first minute was 8 and 
$67.6 \%$ in the fifth minute was 9. Mean Fetus Weight at Early PE $1543.18 \mathrm{~g}$ and at Late PE $2623.91 \mathrm{~g}$ and mean NICU was 37.82 days at early PE and 6.87 days at Late PE. There is a very significant correlation between Fetus Weight (g) and NICU $(\mathrm{R}=-0.84, \mathrm{p}<0.001)$ also there is a significant difference between the presence of IUGR on early and Late PE (Fisher's Exact Test $=8.192, \mathrm{p}=0.008$ ). There is a significant difference on CPR values on early and late PE (T-test = 2.127, $\mathrm{p}=0.041$ ).

Keywords: pre-eclampsia, maternal characteristics, screening, uterine artery Doppler

\section{Introduction}

Pre-eclampsia (PE) is one of the hypertensive pregnancy disorders, de novo proteinuric hypertension that develops after 20 weeks of gestation, which affects from 3 to $5 \%$ of pregnant women. It is a systemic disorder associated with high maternal and neonatal morbidity and mortality (Roberts JM. 2001.) In addition, PE frequently coexists with intrauterine growth restriction (IUGR, also called fetal growth restriction), placental abruption, and the need for iatrogenic preterm delivery, which are additional major causes of adverse outcomes. (Poon LC et al. 2010). Its diagnosis is based on clinical features, such as high blood pressure and proteinuria, which are the terminal events of a cascade of phenomena that are likely initiated during placental formation and development in the late first trimester of gestation (Redman CWG. 2009). Increasingly, early-onset pre-eclampsia is considered to be a more severe form of the disease than is the late-onset condition (Romero R. 2008). Many groups have focused on methods to predict pre-eclampsia in order to identify accurately pregnant women who are at risk (Nicolaides KH. 2007). Pregnancy-related $\mathrm{HD}$ are thought to be the consequence of impaired trophoblastic invasion of the maternal spiral arteries, resulting in maintenance of vessels of high resistance, inadequate perfusion of the placenta, tissue injury, and increased production of vasoconstrictive substances. In these cases, there are qualitative and quantitative changes in the maternal uterine artery (UA) Doppler waveforms. Maternal uterine artery (UtA) Doppler at 22-24 weeks of gestation has become the most reliable tool for prediction of pre-eclampsia; this diagnostic test has the ability to predict nearly $50 \%$ of instances of any form of the disease and approximately $85 \%$ of cases of severe or early-onset disease (Parra M et al. 2005), (Yu CK et al. 2005). However, UtA Doppler performed in the final weeks of the first trimester of gestation $(11+0$ to $13+6$ weeks) varies much more in its predictive ability for early-onset pre-eclampsia than it does at the second-trimester scan. (Martin AM et al. 2001), (Plasencia W et al. 2007) The majority of the studies evaluated the UA Doppler in the second trimester of pregnancy, supposedly because the trophoblastic invasion of the maternal spiral arteries has finished at this point. On the other hand, there is now strong evidence demonstrating that abnormal UA Doppler in the first trimester of pregnancy is also 
associated with abnormalities in trophoblast invasion. The concept of early and late PE is more modern, and it is widely accepted that these two entities have different etiologies and should be regarded as different forms of the disease. (Von Dadelszen $P$ et al. 2003), (Huppertz B. 2008). Early-onset PE (before 34 weeks) is commonly associated with abnormal uterine artery Doppler, fetal growth restriction (FGR), and adverse maternal and neonatal outcomes. (Ness RB et. al. 2006), (Murphy DJ et al. 2000), (Walker JJ. 2000). In contrast, late-onset PE (after 34 weeks) is mostly associated with normal or slight increased uterine resistance index, a low rate of fetal involvement, and more favorable perinatal outcomes. (Ness RB. 2006), (Sibai B. 2005). Early-onset PE and FGR are placenta-mediated diseases (Crispi F et al. 2006) who reported placental growth factor (PIGF) as a useful second-trimester screening test for this form of the disease, but not for late-onset PE/FGR. Maternal risk factors: age, parity, previous obstetric history, etc. Maternal echocardiography might identify at 24 weeks gestation patients who subsequently develop early severe maternal and fetal complications through the assessment of maternal hemodynamics suggesting an involvement of the whole cardiovascular system in the placental mediated disorder. (Vasapollo B et al. 2008), (Valensise H et al. 2006), (Novelli GP et al. 2003), (Bosio PM et al. 1999). The abnormal placentation that characterizes pre-eclampsia is associated with an increased resistance in the utero-placental circulation. Ultrasonography evidence of this resistance includes the presence of a diastolic 'notch' in the Doppler waveform of the uterine artery or an increase in that vessel's pulsation index (PI). (Campbell S et al. 1983) Being an objectively measured continuous variable, the latter is preferable to the somewhat subjective assessment of 'notching'. (Lees C. 2010) It has been suggested that Doppler studies might be most predictive if performed in a sequential fashion in both the first and second trimesters. (Napolitano R et al. 2012) However, such an approach would preclude the early initiation of prophylaxis. Other potential ultrasonography parameters for the prediction of pre-eclampsia include 3D power Doppler assessment of placental volume and vascularity, maternal MCA Doppler indices (Belfort $M$ et al. 2012). Further research will determine whether any of these is superior to uterine artery Doppler analysis.

\section{Materials and Methods}

This is a retrospective cohort study, during January - December 2017, of women who have had Pre-eclampsia at a tertiary referral University Hospital of Obstetrics and Gynecology "Koço Gliozheni" in Tirana, Albania. In total were 62 women with Preeclampsia during this period of time. Maternal demographic characteristics, ultrasonography measurements (uterine artery color Doppler examination at 22-24 weeks of gestation) and neonatal data were collected from the case notes (medical records and were recorded in a computer database). The ultrasound machine used was Aloka Echo Camera L. All ultrasound examinations were performed by an obstetrician. PE cases were managed by medical team, obstetric consultants. Data were collected on patient age, parity, gestational age at time of delivery, history of previous PE, mean arterial pressure and Doppler ultrasound parameters. Neonatal 
evaluation included neonatal birth weight, Apgar score at 1 and 5 minutes, neonatal gender, generality admission to the neonatal intensive care unit. All data were calculated with SPSS 15.0. T-test, Chi-Square test, Fisher test and Correlation were used for statistical analysis.

\section{Results and Discussions}

In total, 62 women with Pre-eclampsia were classified: 32\% Early PE (before 34 weeks) and 68\% Late PE (after 34 weeks). At the table Nr.1 we can see that the mean age of mothers with PE was 32.65 years old, Std. deviation $=5.851$ years. It was interesting to see how maternal age was different in the two groups of preeclampsia: early onset PE are older with a higher percentage of women over 35 years than late onset PE. Although it is well known that an age more than 35 years is linked to a higher risk for preeclampsia, the importance of age in early and late preeclampsia has not been clearly reported so far. An intriguing hypothesis could be that an older age might negatively influence the placental process, but this should be confirmed on larger numbers with the whole set of hemodynamic data. The mean age of mother at Early PE was 34.45 years old and at Late PE was 31.78 years old. (Table nr.2).

Parity was also a maternal characteristic that could interfere in the trophoblastic invasion of the maternal spiral arteries in the present study. Pre-eclampsia is more common among women who: has had a baby ( $50 \%$ second parity, $14.7 \%$ third parity, $2.9 \%$ multiparity). At the Table Nr.1 are summarized the neonatal complications, like as: Low Birth Weight (mean 2200-2300 g) and some of them IUGR. It has also been observed that women carrying male fetuses $(62 \%)$ are at slightly greater risk for PE than are women carrying female fetuses (38\%). We can admit that $29 \%$ of women of PE have had previous PE in their pregnancies.

The mean arterial pressure is calculated by dividing the sum of the systolic and twice the diastolic blood pressures by three and is thus easily measurable. As we can see that the mean systolic blood pressure is $160 \mathrm{~mm} \mathrm{Hg}$ (for Early PE 167.7 and for Late PE $156.3 \mathrm{~mm} \mathrm{Hg}$ ) and mean diastolic blood pressure is $96.5 \mathrm{~mm} \mathrm{Hg}$ (for Early PE 99.55 and for Late PE 95 mm Hg). (Table Nr.1 and Nr.3, Fig. Nr.1).

The utility of Doppler analysis of the uterine artery in predicting pre-eclampsia has been extensively studied initially in the mid-second trimester and more recently in early pregnancy. The abnormal placentation that characterizes pre-eclampsia is associated with an increased resistance (RI) in the utero-placental circulation. Ultrasonography evidence of this resistance includes the presence of a diastolic 'notch' in the Doppler waveform of the uterine artery or an increase in that vessel's pulsation index (PI). In our study, the mean UA RI was calculated in both trimesters of pregnancy.

We considered abnormal values greater than 0.85 and 0.77 in the first and second trimester, respectively. Being an objectively measured continuous variable, the latter is preferable to the somewhat subjective assessment of 'notching'. At the table Nr.3 
we can see that mean CPR at Early PE is 1.3 (around 1) and at Late PE 1.79. We can see that in Doppler examination 26\% had bilateral notch at uterine artery, $12 \%$ notch at AU Dexter, $15 \%$ notch at AU Sinister and 47,1\% without notch (figure nr.2).

PE is associated with an increase in preterm birth and neonatal outcome. Fetal intrauterine growth retardation (IUGR + PE $38 \%$ ), Low birth weight ( $<2500 \mathrm{~g}$ ), low Apgar score which needs admission in neonatal intensive care unit. Mean Fetus Weight at Early PE $1543.18 \mathrm{~g}$ and at Late PE $2623.91 \mathrm{~g}$ and mean days that neonatal had stayed in the Intensive Care Unit was 37.82 days at early PE and 6.87 at Late PE. (Table Nr.2) In the figure Nr.4 we can see that $58.8 \%$ APGAR score in the first minute was 8 and $67.6 \%$ in the fifth minute was 9 . From the table nr.4. we can see that exist a very significant correlation between Fetus Weight (g) and NICU, Apgar min 1 and Apgar min 5. The lower fetus weight, higher is NICU $(\mathrm{R}=-0.84)$. On the other side the lower fetus weight, lower is the APGAR min 1 and $\min 5(\mathrm{R}=0.574$ and $\mathrm{R}=0.688)$. Also as higher the APGAR min 1 and min 5 as lower the NICU. There is a significant difference between the presence of IUGR on early and Late PE. As we can see from figure nr.5 the presence of IUGR is higher on early PE (Fisher's Exact Test $=8.192$, $\mathrm{df}=1, \mathrm{p}=0.008$ (2-sided). There is a significant difference on CPR values on early and late PE (T-test $=-2.127, \mathrm{p}=0.041)$. (see the tab. Nr. 5)

\section{Conclusion}

Abnormal uterine artery Doppler studies in the first and second trimester combining with maternal factors are useful to predict PE in low-risk pregnant women and have been associated with subsequent adverse pregnancy outcomes including preeclampsia, fetal growth restriction, and perinatal mortality. Early PE showed: an increased percentage of patients $>35$ years old, an increased PI and an elevated RI of uterine artery Doppler, a higher prevalence of bilateral notching at 24 weeks gestation, a lower gestational week at delivery, a lower neonatal weight centile and some days at the NICU.

\section{References}

[1] Roberts JM, Cooper DW. 2001. Pathogenesis and genetics of preeclampsia. Lancet; 357: 53-56.

[2] Poon LC, Kametas NA, Chelemen T et al. 2010. Maternal risk factors for hypertensive disorders in pregnancy: a multivariate approach. J Hum Hypertens; 24: 104-110.

[3] Redman CWG, Sargent IL. 2009. Placental stress and pre-eclampsia: a revised view. Placenta ; 30 (Suppl A): S38-S42.

[4] Romero R, Kusanovic JP, Than NG, Erez O, Gotsch F, Espinoza J, Edwin S, Chefetz I, Gomez R, Nien JK, Sammar M, Pineles B, Hassan SS, Meiri H, Tal Y, Kuhnreich I, Papp Z, Cuckle HS. 2008. First-trimester maternal serum PP13 in the risk assessment for preeclampsia. Am J Obstet Gynecol ; 199: 122.e1-11. 
[5] Nicolaides KH.2007. Some thoughts on the true value of ultrasound. Ultrasound Obstet Gynecol ; 30: 671-674.

[6] Parra M, Rodrigo R, Barja P, Bosco C, Fernández V, Muñoz H, Soto-Chacón E. 2005. Screening test for preeclampsia through assessment of uteroplacental blood flow and biochemical markers of oxidative stress and endothelial dysfunction. Am J Obstet Gynecol ; 193: 1486-1491.

[7] Yu CK, Smith GC, Papageorghiou AT, Cacho AM, Nicolaides KH. 2005. An integrated model for the prediction of preeclampsia using maternal factors and uterine artery Doppler velocimetry in unselected low-risk women. Am J Obstet Gynecol ; 193: 429-436.

[8] Martin AM, Bindra R, Curcio P, Cicero S, Nicolaides KH. 2001. Screening for pre-eclampsia and fetal growth restriction by uterine artery Doppler at 1114 weeks of gestation. Ultrasound Obstet Gynecol ; 18: 583-586.

[9] Plasencia W, Maiz N, Bonino S, Kaihura C, Nicolaides KH. 2007. Uterine artery Doppler at $11+0$ to $13+6$ weeks in the prediction of preeclampsia. Ultrasound Obstet Gynecol ; 30: 742-749.

[10] Von Dadelszen P, Magee LA, Roberts JM. 2003. Subclassification of preeclampsia. Hypertens Pregnancy.;22:143-148.

[11] Huppertz B. 2008. Placental origins of preeclampsia: challenging the current hypothesis. Hypertension.;51:970 -975.

[12] Ness RB, Sibai BM. 2006. Shared and disparate components of the pathophysiologies of fetal growth restriction and preeclampsia. Am J Obstet Gynecol.;195:40-49.

[13] Murphy DJ, Striate GM. 2000. Mortality and morbidity associated with earlyonset preeclampsia. Hypertens Pregnancy.;19:221-231.

[14] Walker JJ. 2000. Preeclampsia. Lancet.;356:1260 -1265.

[15] Sibai B, Dekker G, Kupferminc M. 2005. Pre-eclampsia. Lancet.;365:785-799

[16] Crispi F, Domínguez C, Llurba E, Martín-Galla'n P, Cabero L, Grataco’s E. 2006. Placental angiogenic growth factors and uterine artery Doppler findings for characterization of different subsets in preeclampsia and in isolated intrauterine growth restriction. Am J Obstet Gynecol.;195:201-207..

[17] Vasapollo B, Novelli GP, Valensise H. 2008. Total vascular resistance and left ventricular morphology as screening tools for complications in pregnancy. Hypertension.; 51:1020 -1026.

[18] Valensise H, Vasapollo B, Novelli GP, Pasqualetti P, Galante A, Arduini D. 2006. Maternal total vascular resistance and concentric geometry: a key to identify uncomplicated gestational hypertension. BJOG.;113:1044-1052. 
[19] Novelli GP, Valensise H, Vasapollo B, Larciprete G, Altomare F, Di Pierro G, Casalino B, Galante A, Arduini D. 2003. Left ventricular concentric geometry as a risk factor in gestational hypertension. Hypertension.; 41:469-475.

[20] Bosio PM, McKenna PJ, Conroy R, O’Herlihy C. 1999. Maternal central hemodynamics in hypertensive disorders of pregnancy. Obstet Gynecol. 94:978 -984.

[21] Campbell S, Diaz-Recasens J, Griffin DR et al. 1983. New Doppler technique for assessing uteroplacental blood flow. Lancet; 1: 675-677.

[22] Lees C. 2010. First-trimester screening for pre-eclampsia and fetal growth restriction: a test seeking both a treatment and an optimal timing. Ultrasound Obstet Gynecol; 35: 647-649.

[23] Napolitano R, Melchiorre K, Arcangeli T et al. 2012. Screening for preeclampsia by using changes in uterine artery Doppler indices with advancing gestation. Prenat Diagn; 32: 180-184.

[24] Belfort M, van Veen T, White GL et al. 2012. Low maternal middle cerebral artery Doppler resistance indices can predict future development of preeclampsia. Ultrasound Obstet Gynecol; 40: 406-411.

Table Nr.1 Maternal and Neonatal parameters

\begin{tabular}{|c|c|c|c|c|c|}
\hline & \multirow{2}{*}{$\begin{array}{l}\text { Minimum } \\
\text { Statistic }\end{array}$} & \multirow{2}{*}{$\begin{array}{l}\text { Maximum } \\
\text { Statistic }\end{array}$} & \multicolumn{2}{|l|}{ Mean } & \multirow{2}{*}{$\begin{array}{l}\text { Std. dev. } \\
\text { Statistic }\end{array}$} \\
\hline & & & Statistic & $\begin{array}{l}\text { Std. } \\
\text { Error }\end{array}$ & \\
\hline Maternal Age & 18 & 45 & 32.65 & 1.003 & 5.851 \\
\hline Parity & 1 & 4 & 1.88 & 0.132 & 0.769 \\
\hline $\begin{array}{l}\text { Maternal } \\
\text { Weight(kg) }\end{array}$ & 66 & 127 & 83.82 & 1.941 & 11.318 \\
\hline $\begin{array}{l}\text { Maternal } \\
\text { Height }(\mathrm{cm})\end{array}$ & 153 & 169 & 161.53 & 0.643 & 3.752 \\
\hline SBP & 140 & 190 & 160.00 & 2.214 & 12.910 \\
\hline DBP & 75 & 110 & 96.47 & 1.204 & 7.020 \\
\hline PI UA & 0.70 & 1.39 & 1.0318 & 0.03527 & 0.20567 \\
\hline PI MCA & 0.60 & 2.80 & 1.6597 & 0.09690 & 0.56504 \\
\hline CPR & 0.70 & 3.59 & 1.6388 & 0.11498 & 0.67046 \\
\hline Fetus Weight (g) & 975 & 3600 & 2274.26 & 130.236 & 759.398 \\
\hline APGAR Min 1 & 2 & 9 & 7.8529 & 0.20740 & 1.20937 \\
\hline APGAR Min 5 & 6 & 9 & 8.6176 & 0.11182 & 0.65202 \\
\hline NICU & 0 & 62 & 16.88 & 3.453 & 20.137 \\
\hline
\end{tabular}

Table Nr.2: Mother's Age 


\begin{tabular}{lllll}
\hline & PE & Mean & Std. Deviation & $\begin{array}{l}\text { Std. Error } \\
\text { Mean }\end{array}$ \\
Age & Early PE & 34.45 & 6.758 & 2.038 \\
& Late PE & 31.78 & 5.308 & 1.107 \\
\hline
\end{tabular}

Table nr.3. Blood Pressure, Doppler Parameters, Fetus Weight and NICU

\begin{tabular}{|c|c|c|c|c|c|c|c|c|}
\hline PE & & SBP & DBP & $\begin{array}{l}\text { PI } \\
\text { UA }\end{array}$ & $\begin{array}{l}\text { PI } \\
\text { MCA }\end{array}$ & CPR & $\begin{array}{l}\text { Fetus } \\
\text { Weight } \\
\text { (g) }\end{array}$ & NICU \\
\hline $\begin{array}{l}\text { Early } \\
\text { DF }\end{array}$ & Mean & 167. & 99.5 & 1.12 & 1.51 & 1.302 & 1543.18 & 37.82 \\
\hline PE & Std. & 14.0 & 6.10 & .162 & .606 & .4280 & 446.667 & 16.424 \\
\hline \multirow[t]{2}{*}{ Late PE } & $\begin{array}{l}\text { Dev } \\
\text { Mean }\end{array}$ & $\begin{array}{l}29 \\
156 \\
30\end{array}$ & $\begin{array}{l}5 \\
95.0 \\
0\end{array}$ & $\begin{array}{l}99 \\
.987 \\
4\end{array}$ & $\begin{array}{l}56 \\
1.73 \\
13\end{array}$ & $\begin{array}{l}0 \\
1.799 \\
6\end{array}$ & 2623.91 & 6.87 \\
\hline & $\begin{array}{l}\text { Std. } \\
\text { Dev }\end{array}$ & $\begin{array}{l}10.7 \\
89\end{array}$ & $\begin{array}{l}7.07 \\
1\end{array}$ & $\begin{array}{l}.212 \\
16\end{array}$ & $\begin{array}{l}.543 \\
23\end{array}$ & $\begin{array}{l}.7124 \\
1\end{array}$ & 615.864 & 12.715 \\
\hline \multirow[t]{2}{*}{ Total } & Mean & $\begin{array}{l}160 . \\
00\end{array}$ & $\begin{array}{l}96.4 \\
7\end{array}$ & $\begin{array}{l}1.03 \\
18\end{array}$ & $\begin{array}{l}1.65 \\
97\end{array}$ & $\begin{array}{l}1.638 \\
8\end{array}$ & 2274.26 & 16.88 \\
\hline & $\begin{array}{l}\text { Std. } \\
\text { Dev. }\end{array}$ & $\begin{array}{l}12.9 \\
10\end{array}$ & $\begin{array}{l}7.02 \\
0\end{array}$ & $\begin{array}{l}.205 \\
67\end{array}$ & $\begin{array}{l}.565 \\
04\end{array}$ & $\begin{array}{l}.6704 \\
6\end{array}$ & 759.398 & 20.137 \\
\hline
\end{tabular}

Tab. Nr. 4. The correlation between Fetus Weight (g) and NICU, APGAR min 1 and $\min 5$.

\begin{tabular}{|c|c|c|c|c|c|}
\hline \multirow[b]{2}{*}{$\begin{array}{l}\text { Fetus } \\
\text { Weight(g) }\end{array}$} & & $\begin{array}{l}\text { Fetus } \\
\text { Weight (g) }\end{array}$ & $\begin{array}{l}\text { APGAR } \\
\min 1\end{array}$ & $\begin{array}{l}\text { APGAR } \\
\text { min } 5\end{array}$ & NICU \\
\hline & $\begin{array}{l}\text { Pearson } \\
\text { Correlation }\end{array}$ & 1 & $.574(* *)$ & $.688(* *)$ & $\begin{array}{l}- \\
.841\left(^{* *}\right.\end{array}$ \\
\hline \multirow{3}{*}{$\begin{array}{l}\text { APGAR min } \\
1\end{array}$} & Sig. (2-tailed) & & .000 & .000 & .000 \\
\hline & $\begin{array}{l}\text { Pearson } \\
\text { Correlation }\end{array}$ & $.574(* *)$ & 1 & $.810(* *)$ & $\begin{array}{l}- \\
.659\left(^{* *}\right. \\
)^{*}\end{array}$ \\
\hline & Sig. (2-tailed) & .000 & & .000 & .000 \\
\hline $\begin{array}{l}\text { APGAR min } \\
5\end{array}$ & $\begin{array}{l}\text { Pearson } \\
\text { Correlation }\end{array}$ & $.688(* *)$ & $.810(* *)$ & 1 & $\begin{array}{l}- \\
.800\left(^{* *}\right. \\
)\end{array}$ \\
\hline \multirow{3}{*}{ NICU } & Sig. (2-tailed) & .000 & .000 & & .000 \\
\hline & $\begin{array}{l}\text { Pearson } \\
\text { Correlation }\end{array}$ & $-.841\left(^{* *}\right)$ & $-.659(* *)$ & $-.800\left(^{* *}\right)$ & 1 \\
\hline & Sig. (2-tailed) & .000 & .000 & .000 & \\
\hline
\end{tabular}


Tab. Nr.5. CPR values on early and late PE

\begin{tabular}{lllll}
\hline \multirow{3}{*}{ CPR } & PE & Mean & Std. dev & Std. Error Mean \\
& Early PE & 1.3027 & .42800 & .12905 \\
& Late PE & 1.7996 & .71241 & .14855 \\
\hline
\end{tabular}

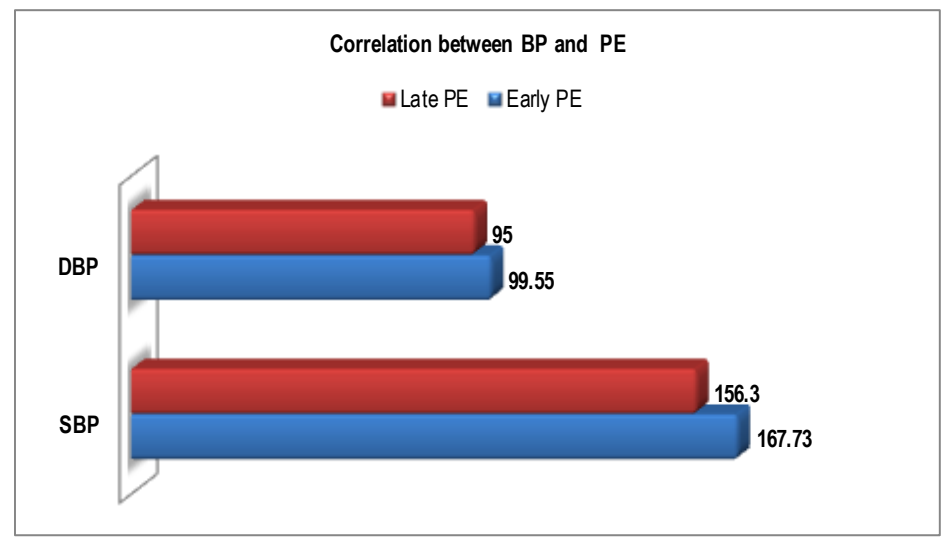

Fig. Nr. 1. Sistolic and Diastolic Blood Pressure

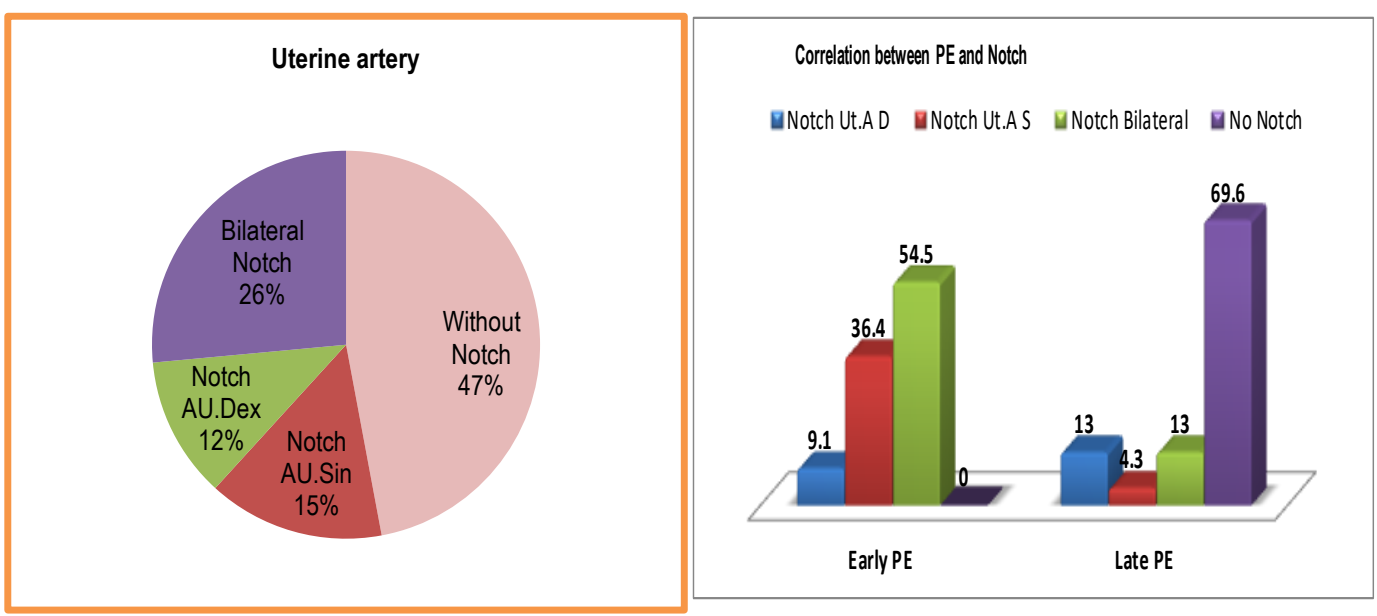

Fig. Nr.2. Doppler of Uterine Artery Fig. Nr.7. Doppler of Uterine Artery 

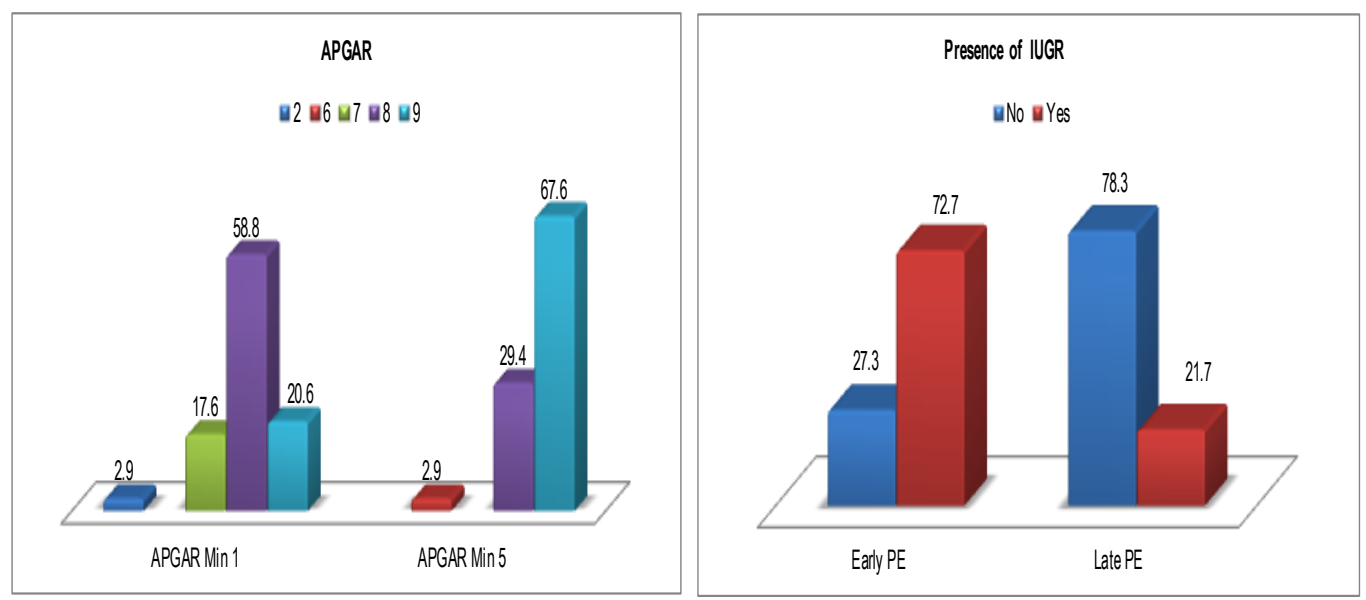

Fig. Nr.4. APGAR minute $1 \&$ 5Fig. Nr.5. The presence of IUGR

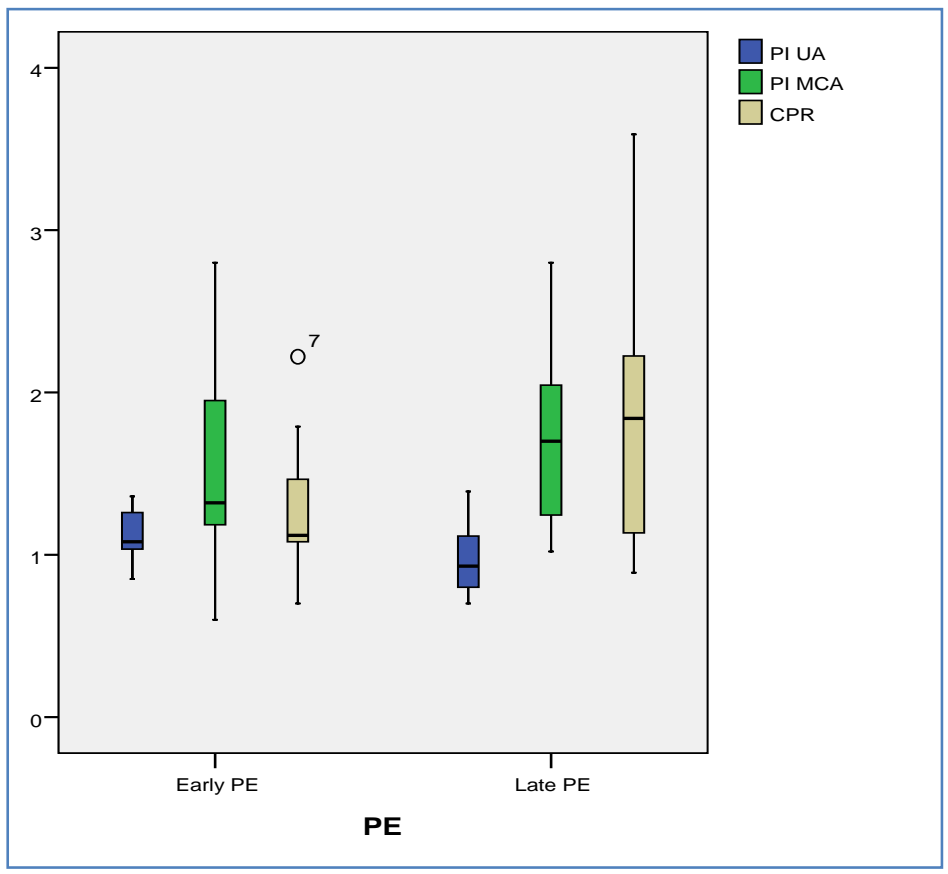

Fig. nr. 6. The values of PI UA, PI MCA, CPR on early and Late PE 